\title{
A Suggested Program for Developing English Speaking Skills of Preparatory Pupils in the Light of Collaborative Learning in a Blended Learning Environment
}

\author{
Hussein Muhammad Muhammad Hassan Al-Qassas*
}

\author{
Supervised by \\ Dr. Aida Abdel Maksoud Zaher** \\ Dr. Amira Al-Amir Khater***
}

\begin{abstract}
The present study aimed at investigating the effect of a suggested program based on Collaborative Learning in a Blended Learning environment in developing preparatory stage students' overall speaking skills and sub-skills (pronunciation, Grammatical Competence (Vocabulary \& Grammar) Discourse Competence, Fluency and Non-verbal skills). The study adopts the one -experimental group design. Consequently, a group of 41 first year preparatory students were randomly selected and received the program. The study applied a checklist of the speaking skills appropriate for first year preparatory students; a pre/post - speaking test that are suitable for the first-year preparatory students and speaking rubric, validated and approved by a panel of jury (EFL specialists), to achieve the study aim. The suggested program was taught over nearly three months, for eighteen sessions of two hours each, nine sessions were delivered on face to face mode and the other nine sessions were delivered on on-line mode. Results provided support for the hypotheses of the study and showed that the post-test mean scores of the experimental group revealed huge effect size of the suggested program on developing students' overall speaking skill and sub-skills. Besides, analyzing the attitudes scale revealed huge effect of the program on promoting speaking attitudes. Moreover, the qualitative analysis showed students' strong positive attitudes towards the program. It was concluded that the program based on the Collaborative Learning in a Blended Learning environment proved to be effective in improving First year preparatory stage students ' speaking skills and on promoting a strong positive attitude towards it.
\end{abstract}

Key words: Collaborative Learning - Blended Learning-Speaking Skills - EFL/ESL.

\section{Introduction}

One of the main purposes of learning English as a foreign language (EFL) is to be able to develop the ability to use the target language to communicate and interact with other people, (Samuda\& Bygate,2008, p.5) as English has become an international lingua franca. (Carlos, 2010, p. 47; Martínez, 2018, p. 1) It is the language of technology, science, medicine, tourism, computer, literature and commerce. Zuheer (2008, p.2) asserts that

\footnotetext{
* (A Teacher of English at Al-Waha Distinguished Official Language School)((TEFL),

Curriculum and Instruction) (Faculty of Girls for Arts, Science and Education-Ain -Shams

University) e-mail: husseinalkassas@gmail.com)

${ }^{* *}$ Professor of (TEFL), Curriculum and Instruction Faculty of Girls for Arts, Science and Education-Ain -Shams University

${ }^{* * *}$ Associate Professor of (TEFL), Curriculum and Instruction Faculty of Girls for Arts, Science and Education-Ain -Shams University
} 
learning a language is learning how to communicate in culturally, socially and academically appropriate ways consistent with the norms and customs of target language users.

Nunan $(2015$, p.48) states that people who know a language are referred to as "speakers of this language", as if speaking integrated all other types of skills. Speaking not only enables students to acquire other skills but it supports other language skills as well. Taking into account speaking is more than a mean of communicating ideas already conceived. It is the principle medium for creating, formulating, and expressing new ideas. (Al-Saleh ,2010, p.1)

Abdel-Wahab (2015, p.13) indicate that speaking is: "The process of building and sharing meaning through the use of verbal and non-verbal symbols, in a variety of contexts." This point led many scholars such as Richards (2008) and Ahmed (2015, p. 31) to consider speaking skills also as interactive and productive that involves producing and receiving and processing information to master the target language. (Al-Saleh, 2010, p. 3)

Sasson (2013, p. 24) declares that acquiring speaking proficiency is one of the hardest skills for English Language Learners (ELL) to achieve. At the beginning stages of second-language acquisition, students are often "stuck in the middle ground of being conversational in English, but lacking in the breadth of English needed for content area success" (Ogle \& Correa-Kovtun, 2010). Again, effective speaking teachers create a nonthreatening environment and encourage learners to leave their comfort zone and engage in tasks that require creative language use. (Nunan, 2015, p. 49). Peck (2001, p.138) asks teachers that activities need to be child centered and communication should be authentic.

Many studies assured the need to apply more effective methods and approaches in teaching speaking to enhance students' ability, tackle the speaking skills and reflect its importance. Ahmed (2015) mentioned that the spoken competence of the secondary students' speaking skills could be achieved by using the Content- Based Instruction. Abdullah (2015) determined the impact of using some interactive teaching strategies on improving the EFL speaking skills for preparatory stage students namely, brainstorming, role playing and classroom discussion. El-Garawany (2014), found that it was an important matter to motivate speaking a foreign language in our classes by a suggested ESP program based on Active Learning strategies on developing oral communication skills- listening and speaking skillsamong Hotel Studies Department students.

Lochana \& Deb (2006, p .2) point out that teacher centered lecture is giving way to a more student-centered, hands-on, practical, flexible, and active learning approaches. Lochana \& Deb (2006, p. 3) indicate that the field of second language teaching is no exception in this paradigm shift. One of the areas that came under this paradigm shift is Collaborative Learning (CL). CL is an educational approach to teaching and learning that involves groups of learners working together to solve a problem, complete a task, or create a product. The goal is to allow students to work together to maximize their own and others' learning. (Maesin, A.et al., 2009, p. 71) The importance of CL has long been emphasized and 
recognized as it is one method that can establish a comfortable and low-threat learning environment in the second language classroom.

Research findings have supported the use of technology in teaching language especially speaking. For example, Tsou, Wang, and Li, (2002, p. 416) conclude that technology has positive influences on students' motivation and attitudes. Stahl et al. (2006, p. 1) present the "Computer Supported Collaborative Learning (CSCL) as an emerging branch of the learning sciences concerned with studying how people can learn together with the help of computers. Laurillard (2009, p.1) "Collaborative technologies offer a range of new ways of supporting learning by enabling learners to share and exchange both ideas and their own digital products".

Many studies have recommended utilizing some effective methods such as Collaborative Learning that gives great attention to training students in developing different language skills. Some of these studies are as follows: Abd El-fataah (2015) examined the effect of some interaction strategies in CL environment using web2 applications on developing skills of designing and producing digital learning objects for higher studies students at faculty of education. Findings of the study showed the effect of the proposed interaction strategies in CL environment. Ibrahim (2015) investigated the effect of an instructional course based on some CL activities on enhancing college students' argumentative practices and developing their awareness of basic argumentative concepts. Findings of the study indicated the effectiveness of the proposed program in the developing participants' argumentative writing concepts and skills as a whole and in separation. Alshalan (2016) examined the effects of Wiki-based collaborative writing on the individual writing performance of ESL students. The findings of this study showed that Wiki-based collaborative writing is a very useful strategy to be used in the field of ESL. Beheery (2016) used three strategies based on collaborative work on developing third year English department students' critical listening skills. Findings of the study indicated the effectiveness of the three strategies on developing the participants' critical listening.

Blended learning, brick and click, brick-and-mortar learning, tailored learning or hybrid learning, all these terms refer to the same thing. The brick is the traditional classroom setting. The traditional setting promotes a social, cooperative and active learning environment. It motivates learners through peer interactions and immediate teacher feedback. It allows both teachers and students to address questions and confusions as they arise. Kösea (2010, p.2794) confirms that BL combines different types of instructional techniques and technologies. Aitken (2010, p.78 \& 79) illustrates that in BL, the teacher combines traditional learning methods with online support tools; such as, blog, chat, instant messaging, course management system, email, podcasting, social networking software, and teleconferencing.

The goal of BL should be to unite the best features of in-class teaching with the best features of online learning, to promote active, self-directed learning opportunities for students (Garnham and Kaleta, 2002). Marsh (2001) suggests the benefit of BL is that it takes the best from self-paced, teacher-led, distance, and classroom delivery to improve 
instruction. BL is a curriculum strategy that lets instructional designers present learning content in the format and medium that seems most appropriate. BL integrates or blends learning programs in different formats to achieve a common goal.

Many studies dealt with and tackled the idea of Blended Learning and the different ways of delivery and teaching and reflected its importance in teaching and in teaching English in particular as follows: Khalaf (2013) investigated the effectiveness of a BL program based on genre discourse analysis in developing English major's critical listening and critical reading skills. Mitry (2013) developed Arab Open University (AOU) students' reading and writing research skills. This was achieved through applying a proposed blended course which employed Web - Quests (WQs) and a developed Blended Reading and Writing Research Model (BRWRM). El-Samouly (2014) investigated the effectiveness of utilizing the BL to improve vocabulary acquisition and reading comprehension skills in EFL among preparatory school students. The findings revealed that the BL approach is more effective than the traditional method both in developing students' vocabulary acquisition and in developing students' reading comprehension skills.

Accordingly, it can be said that developing the speaking skill has become a desire for both the students and the society. The researcher of the present study claims that when developing the listening skill, it is necessary to improve it from the very beginning, and when pupils are still young, before they have fossilized errors in their language competence. Therefore, the present study deals with preparatory pupils as its target.

\section{The Context of the Problem:}

Torky (2006), Badr (2009), Elsayed (2014), Abdel-Wahab (2015), Ahmed (2015), Elkhateeb (2015), Soltan (2015) and Hassan (2015) recommend that speaking skill should be given more time and attention either inside or outside the Egyptian classrooms. According to Pattanpichet (2011, p. 165), using CL enhances students' speaking achievement of 35 undergraduate students enrolled in a fundamental English course at Bangkok University to examine their speaking achievement on an English oral test. Also, Albesher (2012) concluded that using CL is fundamental to improve the writing skills of students of English as a second language. According to El-Samouly (2014, p.124), the importance of BL to improve vocabulary acquisition and reading comprehension skills in EFL among preparatory school students. The BL approach is more effective than the traditional method.

Hubackova, Semradova, Klimova (2011, p.285) suggest that Foreign language (FL) teaching can benefit from BL. The on-line section of a BL based course provides many advantages. It offers authentic listening, video recordings and real-life speaking to substitute communication with native speakers. Also, students choose the place and time of their online sessions. Finally, students can communicate with their teachers at any time.

Ibrahim (2015, p.155) concluded that CL changes the traditional organization of the classroom, as teachers' re-structure the classroom environment from traditional lectures to $\mathrm{CL}$ contexts in which students build upon their personal abilities and make benefits of those of others. 
The researcher believes that the problem of the present study springs from students' low achievement in speaking skills and he also believes that students have weak or neuter attitudes towards speaking English.

The researcher made sure of the existence of the problem through:

1. The researcher own experience as he works as a teacher of English for more than twenty one years at one of the official schools at East -Nasr city Directorate -Cairo Governorate.

2. Administering free informal interviews with 7 supervisors and 11 teachers of English at the preparatory stage. Supervisors assured that: -

- $75 \%$ of the preparatory stage teachers do not vary the teaching strategies and activities that handle the speaking skills. $80 \%$ of the teachers who apply traditional strategies. Also,85\% of the teachers do not teach pronunciation during the lessons. Moreover, $80 \%$ of the Students' refrainment from being involved in speaking activities as it is difficult.

English teachers added that: -

- $90 \%$ of the students suffer from weakness in speaking skills in general. $65 \%$ of the students refused to stand in front of their teachers because they are shy to make mistakes while speaking. Also, the monthly tests rarely involve oral items as it is time-consuming and difficult to administer and very difficult to be assessed specially in the classes with large number of students. In addition, teaching speaking is rarely found as the students do not care about speaking activities for its unusualness in the exams.

3. In addition, the researcher conducted a pilot study, in November ,2018

In order to make sure of the problem, the researcher administered a pilot study based on a speaking test on a sample of 20 first year preparatory stage students (these students will be excluded from the experiment); the speaking test addressed some skills: Producing understandable speech, Repeating words and phrases for clarification, Using appropriate vocabulary range, Composing sentences using correct verb tenses, Adapting a natural rate of speech, Using techniques focusing on details ; and Producing utterances with acceptable pauses or hesitation.

The test results revealed that $80 \%$ of the students showed an evident weakness in speaking skills especially in the interaction and in the transaction skills. $20 \%$ of the students desired not to have an oral test, rather having a written one. While speaking, $70 \%$ of the students tend to be either shy or feel embarrassed to complete their tasks. They tend to leave the tasks behind. They also show a weakness in pronouncing the different words and the phrases.

4. Reviewing the literature and related studies that handled speaking skills in English and tried to develop them at the Egyptian context at different stages as in Kassem (2006), Torky (2006), Amin (2007), Marzouk (2012),Elsayed (2014) and Gaber (2015). These studies insured the existence of this problem. Elshahat (2012), El-Garawany (2014), Elkhateeb (2015) and Soltan (2015).

The previously mentioned evidences emphasize the weakness in speaking skills of the students of the first year preparatory. These points also reveal a problem in the students of the first-year preparatory attitudes which hinders their performance of these skills effectively. According to this problem, the researcher will try to investigate the effectiveness of using a program based on CL in a BL environment in developing speaking skills and their attitudes towards it of students of the first year preparatory. 


\section{Statement of the Problem:}

In light of the previous comments, the problem can be summarized as follows:

The first-year Preparatory English students at Al-Waha school, one of the official schools at EastNasr city educational Directorate - Cairo Governorate, had difficulty in English speaking skills and poor attitudes towards it. Hence, there was a need to use a suggested program based on CL and in a BL to develop their speaking skills of EFL.

In order to tackle this problem, the present study attempts to address the following main question: "What is the effect of a suggested program for developing English speaking skills of preparatory students in the light of $C L$ in a BL environment?"

In order to answer this question, the following sub-questions will be addressed:

1. What are the appropriate speaking skills to be mastered by the first year in the light of the CL and BL instruction approach and according to aims of teaching English at the preparatory stage?

2. What is the suggested perspective of the $\mathrm{CL}$ in a BL instruction program for developing speaking skills for the first-year preparatory stage students and the attitudes towards it?

3. To what extent is the proposed CL and BL instruction program effective in developing the overall speaking skills for first year preparatory stage students?

4. To what extent is the proposed CL and BL instruction program effective in developing each speaking sub-skill for the first-year preparatory stage students?

\section{Research Hypotheses:}

The present study sought to verify the following hypotheses:

1- There is a statistically significant difference between the mean scores of the experimental group students on the pre and post administration of the overall English-speaking skills test in favor of the post-test.

2- There are statistically significant differences between the mean scores of the experimental group on the speaking sub-skills (Pronunciation, Grammatical Competence, discourse Competence, fluency and Non-Verbal) pre and post administration of the test in favor of the post-test.

\section{Methodology of the Study:}

The current study used the following approaches:

I. The descriptive analytical approach:

- In reviewing the previous literature and related studies to speaking skills, BL and CL.

II. The quasi-experimental approach: -In experimenting the suggested BL program to develop speaking skills for the first-year preparatory students and measuring its effects.

\section{Delimitations of the study:}

1- The necessary English language speaking skills for first year preparatory stage students.

2- A randomly chosen sample of the first-year preparatory stage students.

3- Using the CL and the BL environment in instruction.

4- Using the Edmodo plat form as on line way to deliver e-learning and the proper sites and applications.

5- Preparing the units of the program based on the BL and based on the required skills for the prep stage. 
6- The program is implemented in the second semester of the academic year 2018-2019. It started on $17^{\text {th }}$ February 2019 and ended on $20^{\text {th }}$ April 2019. Nineteen sessions, two sessions a week over a period of nine weeks at Al-Waha official school, one of East Nasr city, Cairo governorate, Egypt.

\section{7- Significance of the Study}

This study is expected to be of importance to:

1- EFL teachers to organize effective learning environment in the light of implementing CL and BL in teaching language speaking skills in the Egyptian preparatory schools.

2- Methodology planners to develop English teaching methods based on learner-centered classes.

3- Researchers to pave the way to numerous studies either on speaking, CL, and BL.

4- Students to help them acquire speaking skills effectively and gain the pros of e-learning and the interaction with the peers.

\section{Definition of Terms:}

\section{The Speaking Skill:}

El-Koumy (2004, P.85) defined speaking as an oral process of meaning construction and expression containing a collection of micro-skills, including vocabulary, grammar, pronunciation, etc. from the whole language perspective.

Speaking skill is the ability to speak the target language which involves the use of sounds in the correct patterns of rhythm, intonation and the choice of words in the correct order to convey meaning for communicative purposes with others (Mackey \&Gass, 2005, p.9).

The operational definition of the speaking skills used by the researcher refers to "The first-year preparatory stage students' ability to express themselves orally, fluently and accurately as a result of practicing the oral language speaking skills and sub-skills in five categories namely; pronunciation, Grammatical Competence (Vocabulary\& Grammar) Discourse Competence, Fluency and Non-verbal skills through a suggested program based on CL in a BL environment."

\section{Collaborative Learning:}

Seel (2012, p. 628) defines CL as "a synergic relationship among participants sharing their knowledge or skills, engaged in a specific context using implicit or explicit interaction rules to achieve one or more valuable and situated outcomes".

Jones (2014, pp. 164\&165), on the other hand, defines CL as a learning situation in which students are "working together in a group, building on each other's work, proposing and assessing new innovative ideas and regularly communicating with each other in an open and respectful manner".

Ibrahim (2015, p.64), defined CL is as "A learning context in which two or more students interact and work together to gain a better and deeper understanding of a given controversial issue, develop awareness of its various dimensions and help one another write well-grounded argumentative texts about it".

The researcher adopted the previous definition but with some modifications about CL to be " A learning context for the first preparatory students in which two or more students 
interact and work together to gain a better and deeper understanding of a given controversial issue, develop awareness of its various dimensions and help one another in a BL environment to speak naturally and produce a normal, fluent and accurate speech related to real life situations."

\section{Blended Learning:}

The term BL is used to describe a learning situation that combines several delivery methods with the goal of providing the most efficient and effective instruction experience by such combination." (Harriman, 2004 and Williams, 2003).

BL is generally acknowledged as falling somewhere between these two extremes, incorporating elements of each. (Hanson and Clem, 2006, p. 137) Sharma and Barrett (2007, p. 7) define $\mathrm{BL}$ as "a language course which combines a face-to-face (F2F) classroom component with an appropriate use of technology. The term technology covers a wide range of recent technologies, such as the Internet, CD-ROMs and interactive whiteboards".

The operational definition of the BL used by the researcher refers to "An effective environment and method of delivery where a variety of online resources is provided to the first-year preparatory students by the teacher in addition to face-to-face contact to develop their speaking skills and their attitudes towards speaking skills both verbal and nonverbal and to supply the social interaction between students each other, the students and the content and between the students and their teachers."

\section{Review of Literature}

Review of Literature deals with theoretical background of the main aspects of the research; the first section relates to the speaking skills for the first preparatory students, the second section relates to Collaborative Learning, the third relates to Blended Learning.

\section{Speaking skills}

\section{A) Definition:}

According to Brown, 2001; Florez (2001, p.1) \& Luoma (2004, p.2) speaking is "an interactive constructing process of meaning which involves producing, receiving and processing information..." The form and meaning depend on the context, it includes participants, their collective experiences, the physical environment, and the purposes for speaking. It is often spontaneous, open-ended, and evolving. However, speech is not always unpredictable. Language functions (or patterns) that tend to recur in certain discourse situations can be identified. (Alshahat, 2012, p. 24)

Badr (2009, P.12) sees speaking as 'pupils' ability to express themselves fluently and accurately as a result of practicing the oral language through some active learning techniques such as role play and games." Al shahat (2011, p.18) defines speaking as "the ability to produce intelligible utterances resulting in a fluent and cohesive achievement of a communicative intent for vocabulary, structures and fluency. “

\section{B) The Nature of speaking:}

Speaking tends to differ from written language in its typical grammatical, lexical and discourse patterns. In addition, some of the processing skills needed in speaking differ from those involved in reading and writing. Nunan $(2015$, p. 49) points out that written language is 
characterized by well-formed sentences, which are integrated into structured paragraphs. On the other hand, spoken language consists of short fragmentary utterances, in a range of pronunciation. Fulcher (2003) states that speech differs from written language in a number of respects. A speaker tends to use less formal vocabulary than that in written language, fewer complete sentences, more repetitions and repairs, and more conjunctions linking main clauses, instead of subordination. However, both spoken and written language share the same syntactic and semantic rules (Al Saidy, 2012, p. 27). As for lexis, spoken English has a lower lexical density than written English, using more grammar words and more verb phrases than noun phrases. (Richards, 2008). Spoken language is characterized also by fixed expressions that enhance fluency during speaking. (Segaowitz, 2000 and Richards, 2008, p. 25).

C)The Functions of Speaking: Richards (2008, p. 21) categorizes the functions of speaking into three types. These functions are as follows:

\section{Talk as Interaction:}

The ability to speak in a natural way is required in order to create good communication, establishing or maintaining a relationship. It is sometimes called the interpersonal use of language. It plays an important social role in oiling the wheels of social intercourse. (Rivers, 2000, p.543 and Richards 2008, p. 22).

Consequently, the giving and taking exchanges of information will enable them to create discourse that conveys their intentions in real- life communication. (Richards, 2008, pp. 24-25). Talk as interaction denotes what we refer to as conversation and specifies interaction that serves a primarily social function (Burns, 2013, p.19).

\section{Talk as Transaction:}

Talk as transaction indicates the focus of situations to be on what is said or done. Getting the message across and making oneself understands clearly and accurately is the core focus, rather than the speakers and the way they interact socially with each other (Burns, 2013 , p. 19). In talk as transaction as type of spoken language, learners and teachers get their focus on meaning or on talking (Richards 2008, p. 24).

\section{Talk as Performance:}

This refers to public speaking. It is the talk which transmits information before an audience such as morning talk, teachers in their classroom presentations, public announcements, and speeches. Talk as performance needs to be prepared in the form of a written text, it tends to be in the form of monologue rather than dialogue such as giving a class report about a school trip, conducting a class debate, and giving a lecture. (Richards, 2008, p. 26)

\section{D) Teaching Speaking in the Foreign Language Classes:}

Harmer (2007, P. 123) mentions three reasons for teaching speaking in English inside the classroom. Firstly, the activities used in teaching speaking provide good chances to practice real-life speaking in the classroom safely and simply. Secondly, speaking tasks require using the language students know, consequently providing feedback for both teacher and students about their success and also about the language problems they are experiencing. Finally, elements of the language students know become automated and eloquent as they have opportunities to practice the various elements of language they have stored in their brains. As a result, students gradually become autonomous language users. 
Nunan (2003) stated that teaching English language speaking is to teach the students to: Produce the English speech sounds and sound patterns; Use word and sentence stress, intonation patterns and the rhythm of the second language; Select appropriate words and sentences according to the proper social setting, audience, situation and subject matter; Organize their thoughts in a meaningful and logical sequence; Use language as a means of expressing values and judgments; Use the language quickly and confidently with few unnatural pauses.

\section{Collaborative learning}

\section{A) The Definition of Collaborative learning:}

Graham (2005, p.11) defines CL as 'a small group of learners working together as a team to solve problems, complete a task, or accomplish a common goal'. Seel (2012, p: 628) defines CL as "a synergic relationship among participants sharing their knowledge or skills, engaged in a specific context using implicit or explicit interaction rules to achieve one or more valuable and situated outcomes".

Gokhale (2012, p: 634) illustrates that the term refers to "an instruction method in which students at various performance levels work together in small groups toward a common goal". It refers to "the grouping and pairing of students for the purpose of achieving an academic goal". Jones (2014, p: 164-165) defines CL as a learning situation in which students are "working together in a group, building on each other's work, proposing and assessing new innovative ideas and regularly communicating with each other in an open and respectful manner".

\section{B) Theoretical Background:}

The framework of CL in second language acquisition is mainly grounded on constructivist and social learning theories, and these theories represent two key perspectives: cognitive and sociocognitive (Storch, 2013, p.7). Constructivism states that students are not passive recipients of information when they learn. Social constructivism, on the other hand, claims that knowledge is not only constructed, but it is also co-constructed through social and cultural interactions and collaboration with others, and therefore, it is a social collective product. In this sense, the nature of learning is inherently collaborative. Thus, learning is embedded in its social context and developed through social discourse. (Gillies et al , 2008; Vanderburg, 2006) CL, thus, establishes the community in which knowledge can be cocreated, provides opportunities for individuals to learn from more competent peers, and promotes conceptual development through the experiences of modeling, perspective taking and cognitive challenges" (Udvari-Solner, 2012).

\section{C) Basic features and characteristics of $\mathrm{CL}$}

Drawing on the description of effective CL contexts and the benefits students can experience; the main features and characteristics of CL may be inferred.

\section{1- Interdependence:}

Interdependence refers to the need for information interchange during task performing, work splitting into several roles and explicit knowledge sharing. Social interdependence occurs when the outcomes of individuals are affected by the actions of others; and therefore, 
"positive interdependence exists when actions of individuals promote the achievement of joint goals, resulting in promotive interaction" (Storch,2007).

Davidson \& Major (2014) reflect on the role of CL to enable students to develop independence through interdependence, thus acknowledging its contribution to enhance students' individual abilities and progress as well as those of the whole group. (Mullen et al,2010).

\section{2- Dialogue}

$\mathrm{CL}$ assumes that knowledge is not just a cognitive entity that transfers from one mind to another, but it is a social construct that people reach by talking together. Thus, in CL contexts, the role of students' talk or dialogue as a basic mediating tool for this construction is central and learning is much more of a conversation which leads to sharing meanings and thinking and then to reflective thought (Love et al, 2014; Onrubia \& Engel, 2009).

Appropriation and socialization are two essential mechanisms which emerge out of social interaction between students during collaborative discussions. (Caballe et al.,2010).

\section{3- Reflection}

Reflection represents a link between the individual and the collective thinking. In CL, the individual student gets the opportunity to know about the alternate views and the new information and ideas of his/her peers. S/he then compares and contrasts his/her own ideas with new experiences and assumptions, which helps him/her to reflect on his/her perceptions and understandings and those of others. (Love et al.,2014; Jones, 2014).

\section{D) Elements of Collaborative Learning}

CL refers to an instruction method in which learners at various performance levels work together in small groups toward a common goal. According to Johnson and Johnson (2008), there are five elements of CL that help students to increase their achievement, as follows:

\section{1-Clearly perceived positive interdependence}

Successful CL is the belief that failing at least one student of the group means failing all, so team members are obliged to rely on one another to achieve the goal. If any team members fail to do their part, everyone suffers consequences. Positive interdependence is the belief by each individual that there is value in working with other members and that both individual learning and work products will be better as a result of collaboration. (Laal, 2013, p. 815).

\section{2- Individual Accountability and personal responsibility}

The individual accountability technique helps the group to know which students need more support, encouragement and assistance. Teachers thus need to ensure that not only are all members of the group working collaboratively, but also that every single member of the group takes individual responsibility for making a concerted effort to contribute effectively to the group's work. (Johnson \& Johnson ,2008; Albesher, 2012, p. 44)

\section{3- Face-to-Face Interaction}

Considerable face-to-face interaction is fostered by the positive interdependence element. It can be defined as facilitating, supporting and encouraging individuals to assist each other's efforts. (Laal, 2013, p. 815; Johnson \& Johnson, 2008).

\section{4- Social skills}

Students can learn together successfully when they know and trust each other, communicate accurately, support and help each other, resolve any conflicts and solve 
problems successfully (Johnson \& Johnson, 2008; Laal, 2013, p. 815).. The more skillful collaborators are socially, the more feedback they receive or give on this skill, the higher the achievement of the CL group will be (Graham, 2005; Johnson, et al, 2008,2014).

\section{5- Group Processing}

Group processing gives the students the opportunity to evaluate and maintain their social skills and receive some feedback on their practice during the sessions. (Laal, 2013, p. 815) Moreover, in this stage teachers have an essential role to play in order to help students achieve successful collaborative groups. (Graham, 2005; Johnson \& Johnson, 2008).

\section{Blended Learning}

\section{A) The definition of blended learning}

According to Mason and Rennie (2006, p.12) BL is "other combinations of technologies, locations or pedagogical approaches" while Garrison \& Vaughan (2008, p.5) define BL as "the thoughtful fusion of face-to-face and online learning experiences" emphasizing the need for reflection on traditional approaches and for redesigning learning and teaching in this new terrain. Also, Sharma and Barrett (2007, p.7) define BL as "a language course which combines a face-to-face (F2F) classroom component with an appropriate use of technology. The term technology covers a wide range of recent technologies, such as the Internet, CDs and interactive whiteboards".

\section{B) The Characteristics of blended learning}

Garrison and Vaughan (2008, p.153) state that "BL addresses the issue of quality of teaching and learning. It is an opportunity to address pressing pedagogical concerns, while distinguishing and enhancing the reputation of institutions of higher education as innovative and quality learning institutions". BL provides more guidance for e-learners and adds more flexibility and accessibility for in-class learners by integrating face-to-face learning with webbased learning. Obviously, the most common purpose of BL is the possibility of combining the best of both traditional and online learning (Graham et al., 2003; Kumar, 2007).

Huang, Zhou and Wang (2006) assume that BL has three characteristics. The first is flexibility of providing learning resources. The second is support of learning diversity. As learners are diverse in terms of learning styles, learning proficiency, as well as learning ability. The third is enrichment of eLearning experience.

\section{C)The models of blended learning}

Schools use multiple models and combine them in different ways to create a custommade program. Horn \& Staker (2015, p. 37) agree that most blended courses fit somewhere within the broad parameters of four main models:

\section{1-Rotation Model}

This model includes any course or subject in which students rotate among learning modalities, at least one of which is online learning. Often students rotate among online learning, small-group instruction, and pencil-and-paper assignments at their desks. The key is that the clock or the teacher announces that the time has arrived to rotate, and everyone shifts to their next assigned activity in the course. (Horn \& Staker, 2015, p. 38) 
I- Station Rotation: (also referred to as Classroom Rotation or In-Class Rotation)

This rotation takes place within a classroom or set of classrooms, with at least one station for online learning, students rotate on a fixed schedule or at the teacher's discretion among classroom-based learning modalities. Students break into groups and rotate through other stations which might include activities such as small-group or full-class instruction, group projects, individual tutoring, and pencil-and-paper assignments (Horn \& Staker, 2015, p. 39).

\section{II-Lab Rotation}

In Lab Rotation students walk to a computer lab for the online-learning portion of the course. The idea is to free up teacher time and classroom space by using a computer lab and a different staffing structure for the online component. (Horn \& Staker, 2015, p. 41)

\section{III-Flipped Classroom}

Students consume online lessons or lectures independently. Here, homework and lecture time have merely been switched. Moving the delivery of basic instruction to an online format gives students the opportunity to hit rewind or fast-forward according to their speed of mastery (Horn \& Staker, 2015, p. 43).

\section{VI-Individual Rotation}

In Individual Rotations students do not necessarily rotate to each available station or modality; their daily schedules are customized according to individual playlists (Horn \& Staker, 2015, p. 45).

\section{2-Flex Model}

In the Flex model, the emphasis is on online learning, even if it directs students to offline activities at times. Students move on an individually customized, fluid schedule among learning modalities, and the teacher of record is on-site. The teacher-of-record provides faceto-face support on a flexible and adaptive as-needed basis through activities such as smallgroup instruction, group projects, and individual tutoring. (Horn \& Staker, 2015, p. 47)

\section{3-A La Carte Model}

This model includes any course that a student takes entirely online while also attending a brick-and-mortar school. Suppose a high school does not offer English speaking or physics, for example. Students can take those courses online during study hall or after school, in addition to the regular classes they are taking on campus. (Horn \& Staker, 2015, p. 48)

\section{4-Enriched Virtual}

This model describes courses that offer required face-to-face learning sessions but allow students to do the rest of the work online from wherever they prefer. It is a whole-school experience in which within each course, students divide their time between attending a brickand-mortar campus and learning remotely using online delivery of content and instruction. It differs from the A La Carte model because it is a whole-school experience, not a course-bycourse model. (Horn \& Staker, 2015, p. 50)

\section{Commentary:}

Findings of the previous recent related studies revealed that both CL and BL had several important educational implications. 
* They indicated that instruction following the CL and BL effectively improved the speaking performance of students (Keblawi, 2006; Al-Hazmi,2008; Pattanpichet, 2011; El-Sakka ,2011; Albesher, 2012; Abdel latif, 2012; El-behery, 2013; Khalaf, 2013and El-Garawany,2014)

* They supported the contention that it is beneficial to explicitly and systematically teach students specific strategies for carrying out speaking processes such as: brainstorming, role playing, debates and classroom discussion. (Marzouk,2012; Abdullah,2015; Soltan,2015 and Martínez,2018).

* The CL and BL created the flexibility needed for teachers to individualize instruction. (Chiang,2002; Farve,2004; Wisener,2008; Yilmaz and Orhan,2010; Isman, A et al, ,2012; Moftah,2012; Sweigart,2012; El-behery,2013; El-Garawany,2014 and Elkhateeb, 2015).

\section{Design of the study}

The experimental design employed in the current study was the quasi-experimental one group pre-posttest experimental design to implement the suggested program. Besides, the descriptive analytical method was used for reviewing relevant literature and related studies.

\section{Subjects of the study}

An experimental group consisting of forty-one students was selected randomly from students who were enrolled in the second semester of the academic year 2018-2019 from one of Cairo Official schools, namely Al-Waha School. They have been learning English as a foreign language for seven years. Their age ranged between 13 and 14 years. Thus, the students constituted a homogeneous group in terms of their age, learning background and proficiency.

\section{The Speaking Skills Checklist}

The speaking checklist has been set for determining the most important and suitable speaking and speaking sub-skills skills, needed for students for the preparatory stage, namely the first year, to be instructed in the experimental study. It was composed of five main categories, namely; pronunciation, Grammatical Competence (Vocabulary\& Grammar) Discourse Competence, Fluency and Non-verbal skills to be instructed during the program application. These skills were rated by the panel of jury(the jury consists of seven professors from different universities all over Egypt, they are experts at the field of instruction and methods of teaching English as EFL/ESL) according to the rating scale containing three alternatives: very important, important, and less important.

\section{Validity of the checklist}

The checklist was submitted to a panel of jury specialized in the field of curriculum and instruction (EFL), to determine(a) the degree of importance of each skill, (b) the appropriateness of the skills suggested to first year preparatory stage students. The jury was composed of seven specialists in the field of methods of teaching English. These skills were put in a rating scale which consisted of three levels: very important, important and less important. Each level of importance was given an estimated value to be scored by the researcher. The first level (i.e. very important had (3). The second level (i.e. important) had (2), and the third level (i.e. less important) had (1). Furthermore, the panel of jury was required to add or omit to the list any speaking skills they considered important. Some of the modifications suggested by the panel of jury were: 
Omitting thirteen skills, seven verbal skills and six non-verbal skills, because they were considered either not necessary for first year preparatory stage students or above the students' level of competency. Also, some skills are to be modified. So, the checklist contained $15 \mathrm{sub}$ skills only in its final form instead of the 28 skills in the first form.

After that, the jury indicated that the checklist was valid and the skills were clear and adequate. So, fifteen skills only were selected to be focused on in the current study. Those skills were the ones that received the highest frequency according to the jury's opinions (skills agreed by upon at least $75 \%$ or more of jury members).

\section{The Measurement Tools of Study}

Having determined the required skills through the speaking checklist, the researcher could design the pre-post speaking test, and the speaking rubrics.

The current study made use of the following tools:

1. The Pre-post Speaking Test for measuring students' speaking performance: The speaking pre-posttest consisted of four different items. Students were asked to answer the questions. They were oriented with speaking sub-skills and informed with the allocated time.

The test was constructed after reviewing the following resources:

1- Previous studies concerned with language tests, especially those that are concerned with the topic of how to develop speaking tests.

2- Identifying the skills to be measured by the test according to the speaking skills rubric.

\section{Validity of the Tests}

To measure the test content validity, the first version of the test was submitted to a panel of jury specialized in the field of Curriculum and Instruction of (TEFL) to evaluate the test in terms of content appropriateness and the skills measured.

Most of the jury members suggested that the test questions and items should be printed in color and that students should take their time in answering its items because some items need more time. Some of the jury suggested that the test was very long for the first year and that the test needs to be reduced; so, it was printed in color, suitable pausing between each question and between the different items. The items of the test were shortened to four questions rather than seven questions.

\section{Reliability of the Test}

In order to establish the reliability of the test, it was administered to a randomly selected group of 20 students then the test was administered one more time after two weeks to the same 20 students. Then, the Pearson Correlation Coefficient (Pearson $\boldsymbol{R}$ test) was calculated. To verify the reliability of the test, The IPM SPSS statistics program (version 23) was used for analyzing the scores. The reliability coefficient was estimated. The reliability coefficient was 0.923 which indicates a fairly strong positive relationship (as it was more than 0.7). Therefore, the test is considered a reliable tool for the purpose of the present study. 


\section{The Correction Rubrics.}

The rubric of the rating scale was designed in the light of the speaking skills identified in the speaking skills checklist of the present study and reviewing the related previous literature and studies so rubrics of the rating scale covered all speaking skills.

\section{The Suggested Program based on the CL in a BL environment}

\section{A) Rationale}

In a CL setting, students are challenged both socially and emotionally as they have the opportunity to converse with peers, present and defend ideas, exchange diverse beliefs, question other conceptual frameworks, and are actively engaged (Srinivas, H., 2011).

CL makes a significant shift away from the typical teacher-centered or lecture-centered inside school classrooms. Teachers who use CL approaches tend to think of themselves less as expert transmitters of knowledge to students.

BL maximizes the best advantages of face-to-face learning and multiple technologies to deliver learning. Online learning environments have been criticized for its lack of human interaction and, for this reason, there has been an increasing movement toward BL approaches where students can have opportunities for both online and offline interaction with their teachers and classmates (Allen \& Seaman,2003).

BL methods are effective in facilitating the process of traditional and online CL (CarrChellman et al., 2000; Gabriel, 2004; Curtis \& Lawson, 2001).

\section{B) Assumptions of the Program:}

The suggested program was based on the following assumptions in the light of speaking skills definition and the CL and BL instruction approaches to language learning:

1. Speaking is an interactive process of constructing meaning that involves producing, receiving and processing information. Its form and meaning are dependent on the context .

2. The process of speaking in the suggested in the CL and BL program is recursive and includes many features. Thus, all of the program objectives and activities are distributed among the lessons and repeated for more consolidation.

3. The principles of the $\mathrm{CL}$ and $\mathrm{BL}$ instruction were followed and taken into consideration in designing the program. These principles are as follows: -

CL and BL create an interactive environment for developing students' speaking skills.

BL allows learners to take advantages of both modes of delivery, traditional and elearning, and enable the development of new learning strategies.

CL and BL environment encourage students to form positive speaking attitudes.

$\mathrm{CL}$ and BL are learner-centered, so learners are considered active participants in their learning process. Thus, learners share more responsibilities in their language learning.

CL and BL employ learner-learner interaction and learner-teacher interaction as well.

CL in a BL environment construct students' speaking knowledge.

CL enhances active learning and students' speaking autonomy as well as high levels of social presence. 


\section{C) Aim of the Suggested Program}

1- Develop EFL students' speaking skills. This is carried out in the light of using the CL in a BL environment. The speaking skills to be developed belonged to five categories namely; Pronunciation, Grammatical Competence (Vocabulary\& Grammar), Discourse Competence, Fluency \&Non- Verbal Sub-skills.

2- Encourage the first prep students of Al-Waha school to practice EFL speaking skills on and outside of school.

3- Distinguish between the different usages of Web2.0 applications.

4- Enhance the confidence level of the first prep students of Al-Waha school in using new technological applications in their future career.

5- Develop cooperation among the first prep students of Al-Waha school.

\section{D) Learning Outcomes of the Suggested Program}

By the end of the suggested program, first year prep students are expected to be able to:

Produce the sounds of English correctly; Use stress patterns and intonation correctly; Use variety of relevant vocabulary for the context; Focus on key vocabulary; Use different structures; Use correct verb tenses; Adapt a natural rate of speech; Express basic needs by making affirmative/negative statements when necessary; Speak fluently; Perform the clarity of the message by speaking naturally; Use the appropriate gestures and body language; Use facial expression; Make eye contact; Use the appropriate tone of voice and voice volume to express feelings; Produce utterances with acceptable pauses or hesitation.

\section{Description of the Program:}

This program was geared for first year preparatory students at Al-Waha school, one of the official schools at East Nasr City educational zone at Cairo governorate, in an attempt to develop their speaking skills of EFL. It included content about the speaking skills, necessary for understanding English native speakers, delivered in the form of BL and used group work and pair work. The program covered five main speaking skills categories namely; Pronunciation, Grammatical Competence (Vocabulary\& Grammar), Discourse Competence, Fluency \&Non- Verbal Sub-skills. These categories have fifteen speaking subskills.

\section{Content of the Program:}

This program included eighteen sessions discussing the above stated fifteen speaking skills classified under each of the five categories were taught throughout two introductory sessions and the program's four units.

\section{A) Testing the first hypothesis:}

"There is a statistically significant difference between the mean scores of the experimental group students on the pre and post administration of the overall English-speaking skills test in favor of the post-test".

To verify the validity of the first hypothesis, Paired Samples t-test was used to compare the pre-and post-application of the overall English-speaking skills test. The SPSS statistics program (version 23) was also, used for analyzing the scores. The Paired Samples t-test results indicated that there was a statistically significant difference between the mean scores 
of the experimental group on the overall speaking skills on the pre-test vs. the post-test in favor of the post-test.

Table (1)

Overall Speaking Skill t-Test Results Comparing the Pre-Test Vs. The Post-Test of The Experimental Group on The Overall Speaking Skills.

\begin{tabular}{|c|c|c|c|c|c|c|c|}
\hline \multicolumn{2}{|l|}{ Tests } & $\mathbf{N}$ & Mean & S.D & df & "t" value & Sig. Level \\
\hline \multirow{2}{*}{$\begin{array}{l}\text { Overall Speaking } \\
\text { Skills }\end{array}$} & Pre-test & 41 & 32.24 & 7.625 & \multirow[t]{2}{*}{40} & \multirow[b]{2}{*}{50.507} & \multirow{2}{*}{$\begin{array}{l}\text { Sig at } \\
0.01\end{array}$} \\
\hline & Post-test & 41 & 70.17 & 7.110 & & & \\
\hline
\end{tabular}

Findings of t-test in table (1) reveal that the pre- application mean score is (32.24) with a standard deviation (7.625) and the post-application mean score is (70.17) with a standard deviation (7.110). The mean score of the paired differences of the experimental group is (37.93), with standard deviation (4.81). The " $\mathrm{t}$ " calculated value (50.507) is significantly higher than the $\mathrm{T}$ tabulated value (2.704) with (40) degrees of freedom at (0.01) level of significance. Thus, there is a significant difference between the mean scores attained by the experimental group on the pretest and those on the posttest in favor of the posttest.

The students' overall speaking skills in all fields can be illustrated in the following chart:

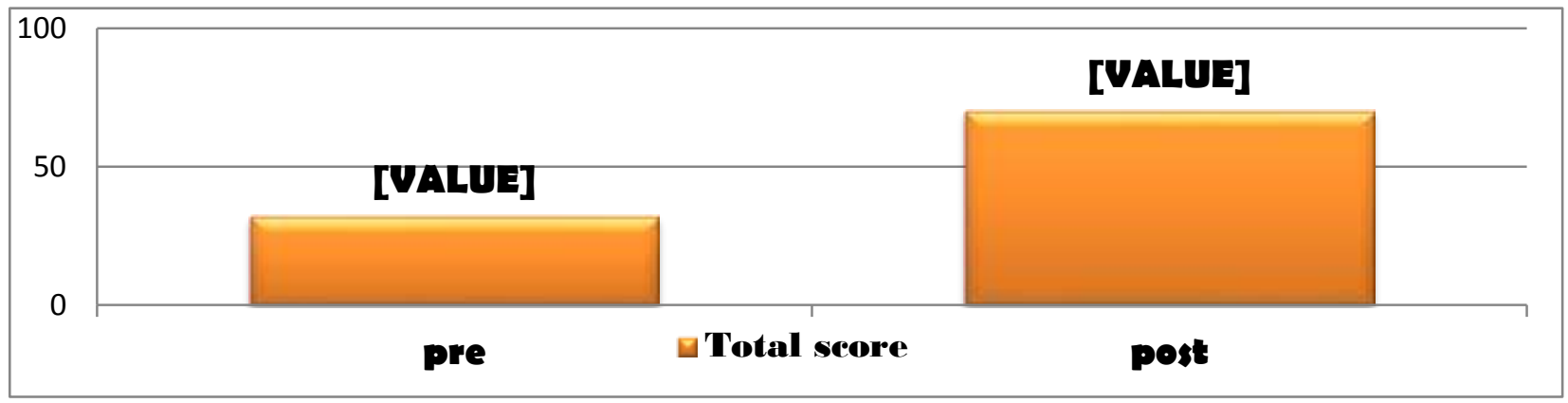

Figure (1): The mean scores of the experimental group pre-posttests on the overall Speaking skill.

This figure shows the results clearly, it reveals that the mean scores of the experimental group students' achievement on the posttest - pretest. The pretest mean score is (32.2439) and the posttest mean score is (70.1707).

The Practical Significance for the suggested Program:

To measure the effect of the suggested CL and the BL program on developing preparatory students' overall speaking skills and to make sure that the results obtained by applying t-test were reliable, the researcher calculated the effect size using two statistical methods (Eta square) and (Cohen's $d$ ).

The researcher used (Eta square) according to the next equation:

$\eta^{2}$

$$
\mathbf{t}^{2}
$$

$$
\mathbf{t}^{2}+\mathbf{d f}
$$

Where: $\quad \boldsymbol{\eta}^{2}($ Eta square $)=$ the calculated effect size, 
$\mathbf{t}=$ the estimated $\mathbf{t}$ value and $\mathbf{d f}=$ the degrees of freedom. As suggested by Hassan (2011:283); Habib and Elmabaredy (2018: 82).

Also, the researcher calculated the effect size (Cohen's d) for the paired samples of the program according to two statistical formulas suggested by Hassan (2011:282)

$$
d=t \sqrt{\frac{2(1-r)}{n}}
$$

Where : $\quad \boldsymbol{r}$ is the correlation between the pre and post tests
$\boldsymbol{t}$ is the estimated $\mathbf{t}$ value
and $\boldsymbol{n}$ is the participants.

Another formula for calculating the Cohen's d for paired or dependent samples is :

$$
\mathbf{d}=\frac{M 1 \quad-\quad M 2}{S D}
$$

Where : $M 1$ is the mean of the pretest and $M 2$ is the mean of the post test $\boldsymbol{S D}$ is the standard deviation.

\begin{tabular}{|c|c|c|c|c|c|c|}
\hline \multirow{2}{*}{ Method } & \multicolumn{6}{|c|}{ Effect Size } \\
\hline & Trivial & Small & Medium & Large & Very Large & Huge \\
\hline Cohen $d$ & $\begin{array}{c}\text { Less than } \\
0.20\end{array}$ & $0.20-0.49$ & $\begin{array}{c}0.50- \\
0.79\end{array}$ & $\begin{array}{c}0.80- \\
1.09\end{array}$ & $1.10-1.49$ & $\begin{array}{c}1.50 \text { Or } \\
\text { More }\end{array}$ \\
\hline $\begin{array}{c}\text { Eta- } \\
\text { Squared } \\
\left(\eta^{2}\right)\end{array}$ & $\begin{array}{c}\text { Less than } \\
0.010\end{array}$ & $\begin{array}{c}0.010- \\
0.058\end{array}$ & $\begin{array}{c}0.059- \\
0.137\end{array}$ & $\begin{array}{c}0.138- \\
0.231\end{array}$ & $\begin{array}{c}0.232- \\
0.359\end{array}$ & $\begin{array}{c}0.360 \text { Or } \\
\text { More }\end{array}$ \\
\hline
\end{tabular}

Table (2): Cohen's d and Eta squared effect size ( $\eta 2)$ critical values (Hassan, 2011:284)

Table (3): The effect size values of the suggested program on overall speaking skills

\begin{tabular}{|l||c|c|c|c||}
\hline \multirow{2}{*}{ Test } & \multicolumn{4}{|c||}{ Effect Size } \\
\cline { 2 - 5 } & \multicolumn{2}{|c|}{ Cohen $\boldsymbol{3}$} & \multicolumn{3}{|c|}{ Eta-Squared $\left(\eta^{2}\right)$} \\
\cline { 2 - 5 } & Value & Size & Value & Size \\
\hline Overall Speaking Skills & $0.1 Y \leq$ & Huge & $\ddots .910$ & Huge \\
\hline
\end{tabular}

Findings of the effect size in table (3) reveal that the Eta squared (0.985) indicates that there is a huge effect size and remarkable increase in the students' overall speaking performance on the posttest. Also, the value of Chen's $d$ (5.124) reveals the same result. This result means that the outcomes went on the predicted direction and thus the first hypothesis is accepted. This provides evidence for the large effect of the suggested program on developing students' speaking skills. Therefore, it can be inferred that the suggested program based on CL in a BL environment has a large effect on the experimental group overall speaking skills on the posttest as compared with their overall speaking skills on the pre-test.

Though, many researchers used the effect size as an good indicator for the effectiveness of educational researches ,treatments and program and if a program has a large 
effect size, it means the program is effective and vice versa,( Hassan, 2011: 296) the researcher used : Haridy's Simple Gain Ratio (H-SGR) in order to measure the effectiveness of the CL in a BL environment for developing speaking skills. (Haridy, 2017:376)

Where: $\mathbf{M 1}=$ the mean of the pre test.

$$
\mathbf{H}-\mathbf{S G R}=\frac{\left(\mathrm{M} 2-\mathbf{M}^{2}\right)}{\mathbf{P}}
$$

$\mathbf{M 2}=$ the mean of the post test.

$\mathbf{P}=$ the total mark of the test.

Table (4): The effectiveness (H-SGR) critical values (Haridy, 2017:376)

\begin{tabular}{|c|c|c|}
\hline \hline Small Effectiveness & Acceptable Effectiveness & $\begin{array}{c}\text { Large } \\
\text { Effectiveness }\end{array}$ \\
\hline \hline $0-0.30$ & $0.31-0.70$ & $0.71-1.0$ \\
\hline
\end{tabular}

As shown in table (4), if the value of the program is between $(0-0.30)$, it means the program has no or week effectiveness and if it is between $(0.31-0.70)$ so, its effectiveness is acceptable and the program is effective but if it is between $(0.71-1.0)$ then , the program has a large effective.

Table (5): The effectiveness of the suggested program on the overall speaking skills.

\begin{tabular}{|c|c|c|}
\hline \multirow{2}{*}{ Test } & \multicolumn{2}{|c|}{ Effectiveness (H-SGR) } \\
& Value & Size \\
\hline Overall Speaking Skills & 0.42 & Acceptable \\
\hline
\end{tabular}

Table (5) indicates that the calculated mean of Haridy's Simple Gain Ratio equals (0. 42) which is between the $(0.31-0.70)$. Therefore, the suggested CL in a BL environment instructional program was acceptable effective in developing English language speaking skills.

\section{B) Verifying the Second Hypothesis:}

"There are statistically significant differences between the mean scores of the experimental group on the speaking sub-skills pre administration of the test vs. post-test in favor of the post-test".

To verify the validity of the second hypothesis, Paired Sample T-Test is used. The Paired Sample t-test results indicate that there are statistically significant differences between the mean scores of the experimental group on the speaking sub-skills in (Pronunciation, Grammatical Competence [Vocabulary\& Grammar], Discourse Competence, Fluency \&NonVerbal Sub-skills) on the pre-test vs. the post-test in favor of the post-test. The difference between the mean scores of the pre-test and post-test will be presented. The presentation will be on students' achievement on the pre-posttest in five speaking sub-skills, and then each subskill will be presented alone. 
Table (6): t-test results comparing the pre vs. the post-test of the experimental group on speaking sub-skills.

\begin{tabular}{|c|c|c|c|c|c|c|c|}
\hline Tests & & $\mathbf{N}$ & $\begin{array}{l}\text { Mean } \\
\text { scores }\end{array}$ & S.D & df & $\begin{array}{l}\text { "t" } \\
\text { value }\end{array}$ & Sig. Level \\
\hline \multirow[t]{2}{*}{ Pronunciation } & Pre-test & 41 & 4.1951 & 1.16661 & & \multirow[t]{2}{*}{39.176} & \multirow[t]{2}{*}{0.01} \\
\hline & \begin{tabular}{|l|} 
Post-test \\
\end{tabular} & 41 & 9.2195 & 1.19399 & & & \\
\hline \multirow{2}{*}{$\begin{array}{l}\text { Grammatical } \\
\text { Competence }\end{array}$} & Pre-test & 41 & 8.3171 & 2.10284 & & \multirow[t]{2}{*}{42.903} & \multirow[t]{2}{*}{0.01} \\
\hline & Post-test & 41 & 18.9756 & 2.15044 & 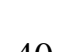 & & \\
\hline \multirow{2}{*}{$\begin{array}{l}\text { Discourse } \\
\text { Competence } \\
\end{array}$} & Pre-test & 41 & 4.1220 & 1.02944 & 40 & \multirow[t]{2}{*}{43.045} & \multirow[t]{2}{*}{0.01} \\
\hline & Post-test & 41 & 9.1951 & 1.03004 & & & \\
\hline \multirow[t]{2}{*}{ Fluency } & Pre-test & 41 & 7.0976 & 1.33800 & & \multirow[t]{2}{*}{32.787} & \multirow[t]{2}{*}{0.01} \\
\hline & Post-test & 41 & 13.4146 & 1.53257 & & & \\
\hline \multirow{2}{*}{$\begin{array}{lll}\text { Non- } & \text { Verbal } & \text { Sub- } \\
\text { skills } & & \\
\end{array}$} & Pre-test & 41 & 8.6829 & 2.42321 & & \multirow{2}{*}{36.498} & \multirow[t]{2}{*}{0.01} \\
\hline & Post-test & 41 & 19.2683 & 2.03745 & & & \\
\hline
\end{tabular}

Findings of t-test in table (6) reveal that: Pronunciation "t" value is (39.176) at "df" (40) and. Grammatical Competence "t" value is (42.903) at "df" (40).Discourse Competence " $t$ " value is (43.045) at "df" (40).Fluency " $t$ " value is (32.787) at "df" (40). Non- Verbal Subskills "t" value is (36.498) at "df" (40). Findings show that there are significant differences at (0.01) level between the mean scores of the experimental group students' achievements on the pre-test and the post-test in the speaking sub-skills in favor of the post-test. More clarity is shown in the following figure:

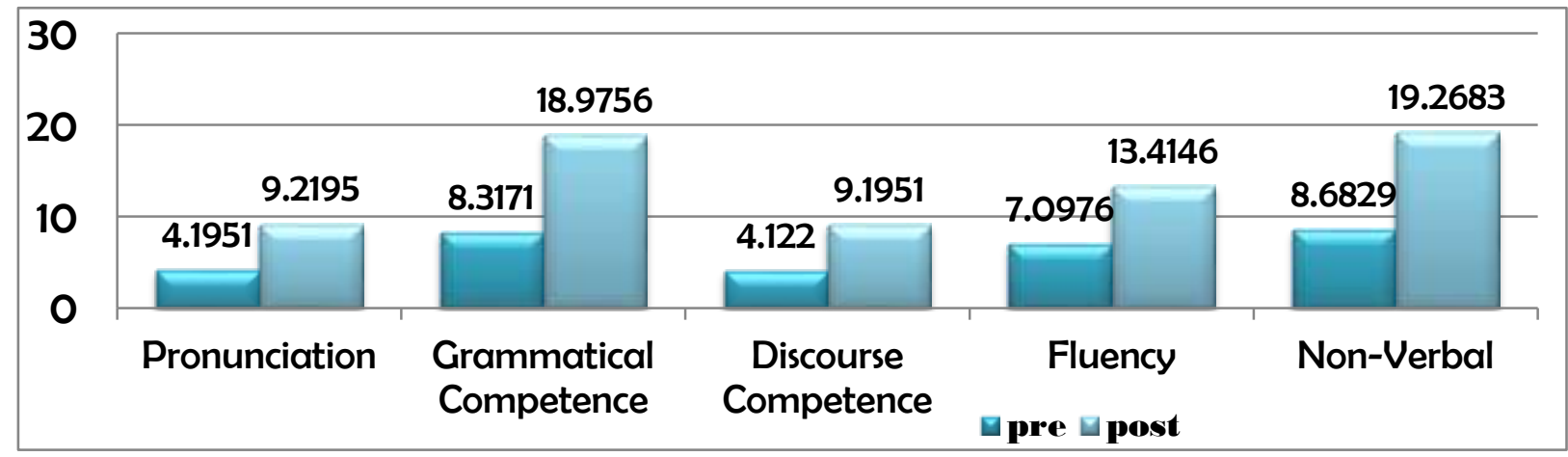

Figure (2): The mean scores of the experimental group the pre-posttests in the speaking sub-skills.

This figure shows simply the mean scores of the experimental group students' achievements on the pretest -posttest as follow: Pronunciation is (4.1951 : 9.2195), Grammatical Competence [Vocabulary\& Grammar] is (8.3171 : 18.9756), Discourse Competence is (4.1220: 9.1951), Fluency is (7.0976: 13.4146), and Non- Verbal Sub is (8.6829:19.2683). 
Table (7): The effect size and the effectiveness of the program on the Speaking SubSkills

\begin{tabular}{|c|c|c|c|c|c|c|}
\hline \multirow{3}{*}{ Test } & \multicolumn{4}{|c|}{ Effect Size } & \multirow{2}{*}{\multicolumn{2}{|c|}{$\begin{array}{c}\text { Effectiveness } \\
\text { (H-SGR) }\end{array}$}} \\
\hline & \multicolumn{2}{|c|}{ Cohen $d$} & \multicolumn{2}{|c|}{$\begin{array}{l}\text { Eta-Squared } \\
\left(\eta^{2}\right)\end{array}$} & & \\
\hline & Value & Size & Value & Size & Value & Size \\
\hline Pronunciation & 4.256 & Huge & 0.975 & Huge & 0.42 & Acceptable \\
\hline Grammatical Competence & 5.014 & Huge & 0.979 & Huge & 0.44 & Acceptable \\
\hline Discourse Competence & 4.931 & Huge & 0.979 & Huge & 0.42 & Acceptable \\
\hline Fluency & 4.357 & Huge & 0.964 & Huge & 0.35 & Acceptable \\
\hline Non- Verbal Sub-skills & 4.659 & Huge & 0.971 & Huge & 0.44 & Acceptable \\
\hline
\end{tabular}

Findings of the effect size of the program in the sub-skills in table (7) reveal that: The Pronunciation skills "Cohen $d$ " value is (4.256) and $\eta 2=(0.97)$ and effectiveness is (0.42). Grammatical Competence skills "Cohen $d$ " value is (5.014) and $\eta 2=(0.97)$ and effectiveness is (0.44). Discourse Competence skills "Cohen $d$ " value is (4.931) and $\eta 2=(0.97)$ and effectiveness is (0.42). Fluency " skills "Cohen $d$ " value is (4.357) and $\eta 2=(0.96)$ and effectiveness is (0.35). Non- Verbal Sub-skills skills "Cohen $d$ " value is (4.659) and $\eta 2=$ $(0.97)$ and effectiveness is (0.44). Findings also indicate huge effect size, according to Etasquared and Cohen's $d$ and indicate an acceptable effectiveness resulted from the application of the suggested program. Therefore, the outcomes went on the predicted direction, thus the second hypothesis is accepted.

Some Sub-Hypotheses emerged from the second hypothesis. These are related to each speaking sub-skill identified in the study.

\section{Discussion of the Results}

\section{Students' Performance on Overall Speaking Skill and Sub-Skills}

The current study aimed at developing some identified speaking skills of a sample of EFL students at Al-Waha school, one of the official schools at Nasr City educational zone, Cairo governorate, Egypt through implementing a suggested program based on CL in a BL environment. The study tried to explore whether there were statistically significant differences in the mean scores of the pretest and posttest of the experimental group on speaking skills achievement as a result of implementing the proposed program. This confirmed the effectiveness of the proposed program based on the CL in a BL environment on developing the identified speaking skills of the experimental students' performance on the posttest, as compared to their achievement in the pretest and posttest. The program has shown consistent and significant improvement students' speaking performance. This is consistent with findings of previous studies such as: (El-Garawany, (2014); Elsayed, (2014); Abdellah, (2014); Shawwa, (2014); Abdullah, (2015); Abdel-Wahab, (2015); Ahmed, (2015); Elkhateeb, (2015) and Soltan, (2015). The significant progress and gain in students' speaking achievement might be attributed to the following factors: 


\section{Following the flexible design of the program:}

Offering two introductory sessions, F2F and online, enabled students to be well aware of the program policy, requirements, outcomes, content, instructional tools, learning strategies, and assessment methods. Technical support was offered to enable students to benefit from the online tools used: Edmodo plat form, You Tube, Google and all the different useful websites and applications used.

Both the online and F2F sessions followed the three-phase format: pre, while, and post- speaking. The pre- speaking phase allowed students to preview the content of the tasks, breaking the ice or listening to a text, watching a video and relax. The while- speaking phase enabled students to practice speaking, shadowing the tasks and direct their attention. The postspeaking phase enhanced students to be reflective speakers, and check their personal knowledge included in the speaking activities and allows students to be creative speakers.

\section{Collaborative Speaking}

During the application of the suggested program, The kind of language used in the CL based program was purposeful and was learned better when it was linked to their social backgrounds. Also, collaborative peer groups provided frequent constructive feedback, and offered positive reinforcement. The teacher and other students were supporters, offering direct assistance, prompts, and encouragement. Collaborative speaking was practiced during both class and on line discussions. This was consistent with Badr (2009), El-Garawany (2014) and Elkhateeb (2015) studies' results.

\section{Peer interaction and various ways of delivery}

The use of pair work and team work allowed the students more chances for practicing speaking activities and the sufficient time for more smoothness and fine-tuning. This was consistent with the study of Ibrahiem (2006) and Amer (2002).

Students were introduced to BL and its various ways of blend. Learners who practiced both traditional learning inside the classrooms with the peer and the teacher interaction as well as the e-learning facilities and the great abilities of the internet and the mass media were more active participants, aware, motivated and independent of their learning process. Moreover, using the CL and the peer interaction among the students provided the students with the responsibility needed to enable the students to transform their mental abilities into an academic performance. This supports Moftah, N. (2012), Tan (2012), Ali (2013), Al-Tonsy (2013), Harb (2013), Khalaf (2013), Mitry (2013), El-Samouly (2014), Ibrahim (2014), Carpenter (2015) and Khaleel (2016) studies' results.

\section{Active Involvement and Collaboration}

BL fosters collaboration in various contexts depends on how the course is designed to involve interaction with others. Also, working in groups and in pairs promote a sense of coownership and social interactions among students. These activities were designed to implement new strategies that benefit second language learning and teaching. Some of these activities make students more responsible in collaborative speaking tasks, contribute to the decision making on all aspects of speaking: content, structure, and language. This supports Sweigart (2012),Dobao (2013),Abd El-fataah (2015), Ibrahim (2015), Alshalan (2016) and Beheery (2016) studies' results. 


\section{Authentic Speaking Materials}

Involving students in authentic speaking tasks and in a real-life situation met students' needs and interests. Through making speaking purposeful, students became better speaking as they had a sense of audience. This is consistent with Torky (2006), Badr (2009), El-Garawany (2014) Elsayed (2014), Habib (2014), and Elkhateeb (2015) studies' results.

\section{Interactive Speaking Strategies and Encouraging Tasks}

Different instructional strategies were used in the F2F and online sessions: discussion, think-pair-share, think aloud, explicit teaching, reciprocal teaching, revise; ask; note (RAN), know; want to know; learn (KWL), and brainstorming. These strategies were based on social constructivism. They enabled students to construct their learning actively. Similarly, the use of Web2.0 technology applications-Edmodo plat form, YouTube-motivated students to be active learners by providing social learning environments. Instead of receiving knowledge, students construct, cooperate, share, and evaluate their outcome-based learning experiences.

Students were given the chance to play roles, discuss and share their ideas in a suitable classroom environment as well as the online environments, thus they were actively engaged in purposeful classroom discussions and the opportunities given to them by the on line part. In such different environments and ways of different delivery, their opinions, ideas and thoughts were appreciated.

\section{Supportive interactive Environment}

The combination of the advantages of e-learning and traditional learning (classroom teaching and peer interaction). The flexibility of e-learning is linked with the social component of face to face teaching as well as the peer interaction. In this method old and new instructional methods are blended more technically.

Both classroom and on-line environments developed students' passion for speaking and increased the likelihood that students applied the activities they had learned as they were interactive, supportive, pleasant, and nonthreatening. This was consistent with Farve (2004), Wisener (2008), Yilmaz and Orhan (2010), El-Sakka (2011), Jefferies (2011),Albesher ( 2012), Abdel latif (2012) had a great effect on students speaking performance.

\section{Feedback}

Feedback occurred in two forms; oral feedback (immediate feedback) either in the class during teaching/learning process or on-line during the synchronous sessions and written or recorded feedback delivered to each student as a private message either f2f or online. Students' speaking assignments were checked and commented on systematically on their personal pages in their e-portfolios as well as on the Edmodo platform. Most students indicated that they liked the feedback, and they reported it as one of the positive aspects of the suggested program. Students were consciously aware of the essential importance of the oral and written feedback for them as speakers. This supports Sun (2000), Ibrahim (2014), Ahmed (2015), Elkhateeb (2015) ,Soltan (2015), Carpenter (2015),Alshalan (2016), Khaleel (2016) and Beheery (2016), studies results which emphasized the importance of feedback in speaking tasks. 
Moreover, to make sure that speaking tasks and sub-skills were achieved, students were re-tested on speaking previous tested activities and make conversations, monologues, descriptions for photos or videos and/or dialogues with a free choice of topics. Students were able to perform speaking tasks and activities and score approximately the same grades. They also could transfer the skills they acquired to other uninstructed topics. This indicated that the program promoted speaking well and with proficiency. This is consistent with Marzouk (2012), El-Garawany (2014), Elsayed (2014), Abdellah (2014), Shawwa (2014), Abdullah (2015), Abdel-Wahab (2015) and Ahmed (2015) results.

\section{Enriched Learning through Student Engagement}

As ESL educators, we understand the importance of student engagement. Traditionally, the more students are engaged, the more learning occurs. Following a BL model can increase learning by over $11 \%$ compared to that in a traditional classroom (Siltzmann, Ely 2009). The reason is simple. Outside of the classroom, students are more engaged with a digital learning tool versus a traditional text. They can interact with content at their own pace, on their own schedule, receive reinforcement of course content and self-select exercises and activities. Students have access to their language success outside the walls of the traditional classroom. BL does not mean a reduction of face-to-face class time. On the contrary, it requires greater participation of learners, greater interaction with content and an overall greater level of engagement.

\section{Informed Teaching: A Clear Picture of Progress}

Using BL allows teachers to be more informed about our students' successes and failures and perhaps even our own. Teachers can choose the most appropriate activities and customize course content to meet curricular and programmatic demands. Therefore, it can be summarized that using BL enabled students to manage their learning. They were encouraged to be self- regulators: they monitored their learning progress.

The results reported in this study coincided with those of El-Deghaidy\& Nouby (2008, p. 1004) who asserted that using blended e- learning improved student teachers' achievement levels, King (2002,p.237) who pointed out that using BL in a teacher education program developed teachers' peer-to-peer interaction in addition to their critical thinking; and Vlachos(2010) who concluded that using BL in the field of Foreign Language education, specifically teaching of English in Europe, enhanced the development of linguistic, sociolinguistic and intercultural competencies, and improved students' cognitive, metacognitive, and social strategies.

\section{Conclusions}

\section{The analysis of the results of the present study has revealed the following conclusions:}

1. The current study provided evidence for the effectiveness of the program based on Collaborative and BL for developing EFL students' overall speaking skill $(\cdot 9 \wedge 0)$ in general and huge effect size on each of the five categories of the speaking skills.

2. The effect size of the Collaborative and BL speaking program on the five categories of speaking skills did not have a big difference from one category to another. 
3. Language learning in Collaborative and BL was viewed as integrative thus; learning in area of language helps learning in other areas.

4. Preparatory school students should use English language purposefully and meaningfully in the CL and BL classes not just for preparation to final exam.

5. Selecting speaking topics that were relevant to students' age, needs and interests were effective in developing students' communication in realistic situations and creating a social context, where students spoke to convey a certain message to a specific audience.

6. Suggested Collaborative and BL speaking program verified its effectiveness in developing speaking skills for first year preparatory school students due to the meaningful engagement and the meaningful use of language through the social interaction among students and their teacher and among them and their classmates.

7. Using Collaborative and BL Instruction increased the chances to cooperation and social communication among students.

8. Speaking instruction should be given more attention in our EFL syllabuses and inside classrooms and universities.

9. More time and efforts should be devoted to develop the speaking skills the subs-kills.

10. Students should have centered-learning and become the core of the learning process as they should take responsibilities in learning English language in general and speaking in particular.

11. There is an indication that using speaking e-portfolios helped students to evaluate their speaking performance, and provided the teacher with the opportunity to follow up students' progress.

12. Collaborative work and supportive feedback were effective factors in the speaking process.

13. There is evidence that BL which combines the face to face traditional teaching with the social interaction between the students and the teacher and between the students and the other students and the e-learning with all the facilities of technology in education plays a great part in developing the students' speaking skills.

14. The strength of using the on line modalities and facilities like websites, educational plat forms and applications was that it provided opportunities for the students to observe themselves and to self-evaluate as well as receive feedback from peers and others as well as their teachers.

15. BL comes in many shapes and sizes - there is no right way or wrong way, no correct formula or single "right" ratio of face-to-face, online time and self-paced activities in and beyond the classroom.

\section{Recommendations}

\section{Based on the study overall results, the following recommendations are laid out:}

Both BL and CL are recommended to be used at higher education level, since it supports students to utilize self-regulation and peer interaction, various ways of delivery and promote students' positive attitudes towards speaking skills, encourages students to practice independently, and ascertains their autonomy and interaction as well as individuality. 
Speaking is urgent to modern daily life needs, entertainment, work requirements and international communication. Therefore, it is recommended to be included effectively and with a great deal in schools and universities English language programs and syllabi.

Speaking should be integrated with other language skills. Speaking development should coincide and go in harmony with the development of other language aspects and skills.

Supportive feedback is recommended to be provided in the speaking process.

Speaking class should be taken seriously. It should take place in a relaxed environment free of tension and confusion.

Raising students' speaking fluency and accuracy are recommended. Speaking needs more linguistic knowledge, cultural awareness, more practice and systematic training.

Real-Life speaking activities are recommended; students should have the opportunity to express themselves freely without any social, political or linguistic restrictions. They should be encouraged to share opinions, express their needs, weaknesses, and strengths.

Both BL and CL are recommended to be used with other language skills like reading, writing and listening. they are also recommended with different subjects.

Further research is required for the effects of CL and BL programs in other stages.

Further research about CL and BL is required for the purpose of exploring its adaptability for addressing individual differences to find out other instructional alternatives.

\section{Suggestions for further studies}

In the light of the results of the present study, the following studies can be suggested:

Further studies may replicate the current study with a larger sample size by including a comparison group or with different stages/ levels of education to have more reliable data.

Further studies are needed for investigating the effectiveness of Blended and CL for developing other areas such as: other speaking genres/ types, other language skills and language aspects.

Further studies may replicate the current study with other speaking strategies or approaches for developing speaking skills.

Further studies are necessary for developing students' speaking skills at higher education of different faculties and colleges of higher education according to their level, specialization and needs and at basic education at different stages such as primary or secondary stages.

\section{References}

- Abdellah, F.M. (2014). "A strategy based on eclectic approach and visual stimuli to develop English speaking skills of workers' university scholars" Unpublished M.A. thesis, Workers' University, Alexandria branch, technology department.

- Ahmed, H. M. (2007)."The Effectiveness of Compensatory Training on Developing English Speaking Skill for First Year Secondary School Students. Unpublished Master Thesis, Faculty of Education, Helwan University. 
- Aitken, J, E. (2010)."Blended Learning for Adaptation to Needs". In Yukiko Inoue "Cases on Online and Blended Learning Technologies in Higher Education: Concepts and Practices". USA. Information Science Reference. IGI Global.pp.76-85.

- Albarracín, D. \& Varges, V. (2010)." Attitudes and Persuasion: From Biology to social responses to persuasive Intent" In S.T, Fisk, D.T, Gilbert, G. Lendzy,(eds.)The Handbook of Social Psychology,(pp. 394-427),Hobken, ND: John Wiley \& Sons.

- Albesher, K.B. (2012)." Developing the writing skills of ESL students through the collaborative learning strategy" Ph.D. thesis, Newcastle University, School of Education, Communication and Language Sciences.

- Al Fiky, A. I. (2011)."Blended Learning: Educational Design, Multi-media, Creative Thinking. Amman (Jordan): Dar Athaqafa for publishing and distribution.

- Ali, M. M. (2013)." The Effect of a Blended Leaning Program on Developing First Year Secondary School Students' Writing Skills and on Reducing Their Writing Apprehension" Ph.D. Theses. Minia University, Faculty of Education, Department of Curricular and Methodology.

- Alsaedi, A, E. (2012). "The Teaching of EFL Speaking in Developed Secondary Public Schools for Females in Saudi Arabia: A Case Study" PhD Thesis, Faculty of Law, Arts $\&$ Social Sciences, School of Humanities. University of Southampton. Retrieved from: http: //eprint.soton.ac.uk

- Atli, I. \& Bergil, A., S. (2012)."The effect of pronunciation instruction on students' overall speaking skills". Procedia - Social and Behavioral Sciences (46). pp:3665 -3671.

- Badr, B. (2009)." The Effect of Using Some Active Learning Techniques on Developing Primary Pupils' speaking Skills". Unpublished Mastery Thesis. Ain Shams University, Faculty of Education, Department of Curriculum and Instruction.

- Barkley, E.F., Cross, K.P., \& Major, C.H. (2005). Collaborative Learning Techniques: A Handbook for College Faculty. San Francisco: Jossey-Bass.

- Beheery, F. A (2016)." The Effect of Use some Collaborative Work Strategies on Developing the Third Year English Department Students' Critical Listening Skills" Unpublished Ph.D. thesis, Ain Shams University, Faculty of Education, Curricular and Instruction Department.

- Bonk, C. J., \& Graham, C. R. (2006). The handbook of blended learning: Global perspectives, local designs. In: Pfeiffer.

- Boonkit, K. (2010)."Enhancing the Development of Speaking Skills for Non-native Speakers of English". (Faculty of Arts, Silpakorn University, Thailand). Procedia, 2 (2010) 1305-1309. 
- Brown, H, Douglas. (2006)."Principles of language learning and teaching". (5 ${ }^{\text {th }}$ edition). Pearson Education Limited.

- Chuo, T. (2007).The Effects of the WebQuest Writing Instruction Program on EFL Learners' Writing Performance, Writing Apprehension, and Perception. TESL-EJ, 11(3), n3.

- Coldwell, J., Craig, A. \& Goold, A. (2011)." Using E-Technologies for active learning”. Interdisciplinary Journal of Information, Knowledge, and Management,6,95-106. http://www.ijikm.org/Volume6/IJIKMv6p095-106Coldwell548.pdf

- Devito, A.J. (2009). "Human communication". Boston, USA: Pearson Education.

- De Wever, B., Van Keer, H., Schellens, T., \& Valcke, M. (2007). Applying multilevel modelling to content analysis data: Methodological issues in the study of role assignment in asynchronous discussion groups. Learning and Instruction, 17, 436-447.

- Driscoll, M. and Carliner, S. (2005) Advanced Web-Based Training Strategies. Blended Learning as a Curriculum Design Strategy. Open Journal of Social Sciences, Vol.3 No.9, September 18, 2015. ASTD Press, New York.

- Elkoumy, A. (2004)."Teaching and Learning English as a Foreign Language: a Comprehensive Approach". 2nd Ed. Educational Resources Information Center (ERIC), USA.

- Ellis, R. (2014). "Principles of instructed second language learning". In M. Celce-Murcia, D. Brinton, \& M. A. Snow. (Eds.), Teaching English as a second or foreign language (4th ed.) (pp. 31-45). Boston, MA: National Geographic Learning/Heinle.

-Elshahat, T., S. (2012)."The Effectiveness of a Suggested Strategy Based on The Communicative Approach in Developing Some Speaking Skills and Values for preparatory Stage Students". Unpublished Master Thesis, Women's College, Ain Shams University.

- Graham, C. R., Allen, S., \& Ure, D. (2003). "Blended Learning Environments: A review of the research literature". Provo.

- Gokhale A.A. (2012)."Collaborative Learning and Critical Thinking". In: Seel N.M. (eds) Encyclopedia of the Sciences of Learning. Springer, Boston, MA

- Good, T.L. and Brophy, J.E. (2000)."Looking in Classrooms". 8th Edition, Longman ... DOI: $10.4236 /$ jep.2011.24038 4,403.

- Hinkel, E. (2011)."Handbook of Research in Second Language Teaching and Learning". Volume 2. New York. Routledge.

- Horn, M.B \& Staker, H. (2015).” Blended: Using Disruptive Innovation to Improve Schools" Jossey-Bass, Wiley Brand 
- Laal, M., \& Laal, M. (2012)."Collaborative learning: what is it?" Procedia-Social and Behavioral Sciences, 31, 491-495.

- Love, A. G., Dietrich, A., Fitzgerald, J., \& Gordon, D.(2014). Integrating collaborative learning inside and outside of the classroom. Journal on Excellence in College Teaching, 25(3\&4), 177-196.

- Luoma, S. (2004). "Assessing speaking". Cambridge: Cambridge University Press.

- Nunan,D.(2015)."Teaching English to speakers of other languages:An introduction"N.York.

- Pan, M. (2016). "Nonverbal Delivery in Speaking Assessment: From an Argument to a Rating Scale Formulation and Validation". Springer Science, Business Media Singapore Pte Ltd.

- Pattanpichet, F.(2011) "The Effects of Using Collaborative Learning to Enhance Students" English Speaking Achievement" J. of College Teaching \&Learning -Vol 8, N.11.

- Perifanoup, M. (2010) " Collaborative Blended learning Methodology", The WebQuest for HRM project, the Lifelong Learning Programme Leonardo da Vinci; The European Commission, PROJECT NUMBER: 2010-1-PL1-LEO05-11466.

- Storch, N. (2005). "Collaborative writing: Product, process, and students' reflections". Journal of Second Language Writing, 14(3), 153-173.

- Storch, N. (2007) Investigating the merits of pair work on a text editing task in ESL classes, Language Teaching Research, 11 (2), 143-159.

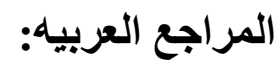

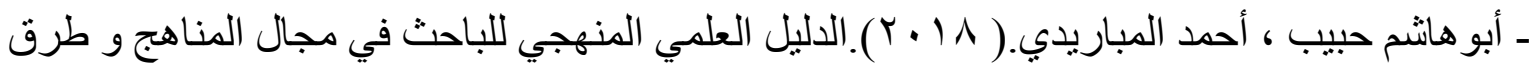

$$
\begin{aligned}
& \text { التدريس و تكنولوجيا التعليم.السويس. هيب. كليه التربيه . }
\end{aligned}
$$

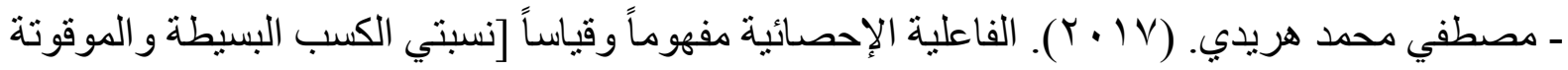

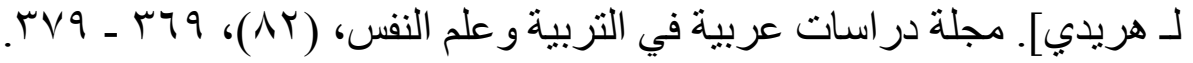




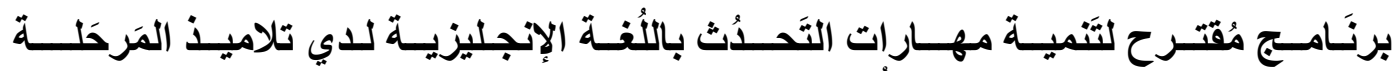

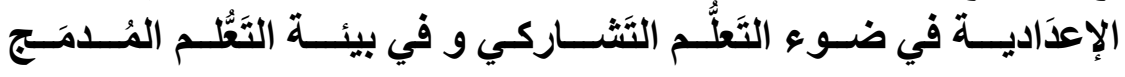

\author{
إعـــاد البــــاحث

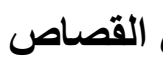

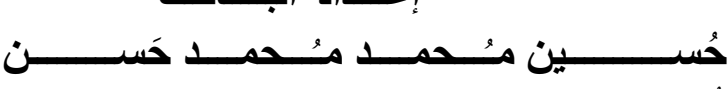

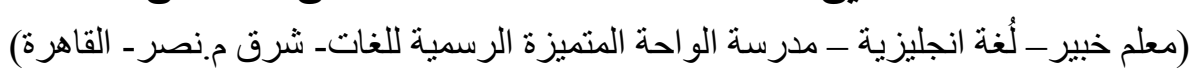 \\ (husseinalkassas@gmail.com)

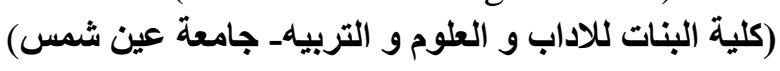

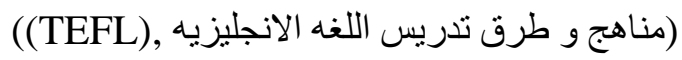

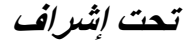

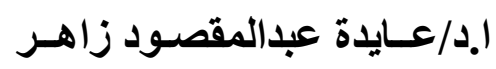 \\ أستاذ المناهج و طرق تدريس اللفة الانجليزية

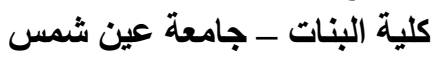

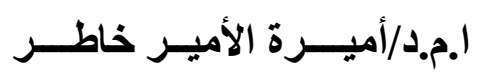

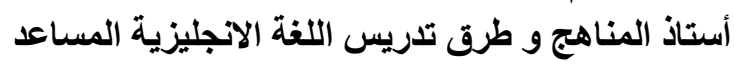

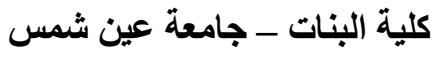

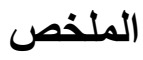

تهدف هذة الدر اسه الي قياس تاثير برنامج مقترح قائم علي التعلم التشاركي و من خلال بيئة التعلم

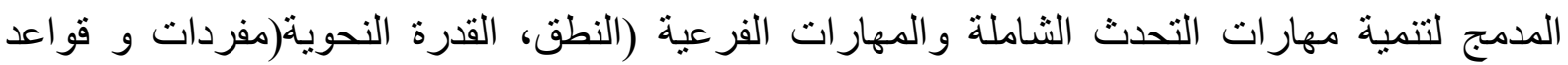

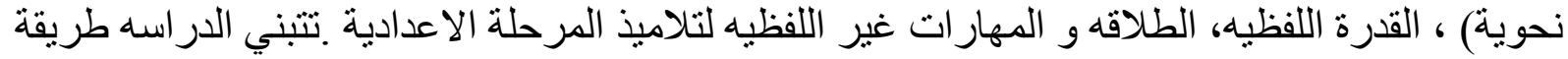

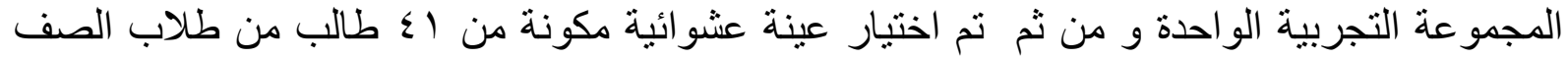

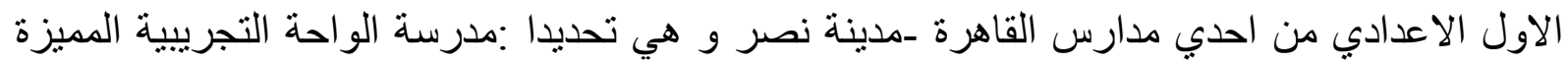

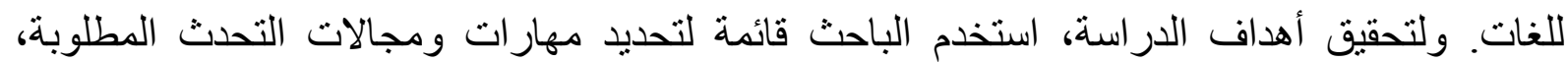

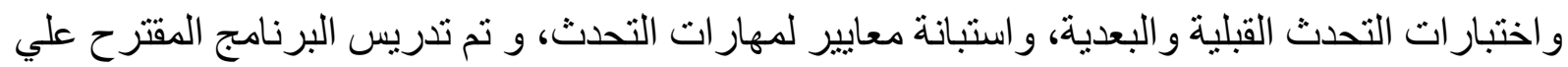

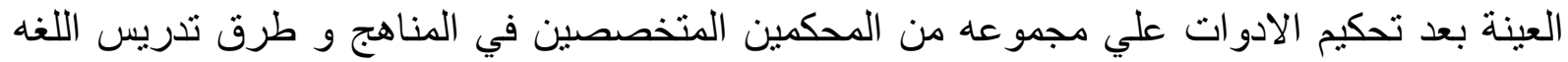

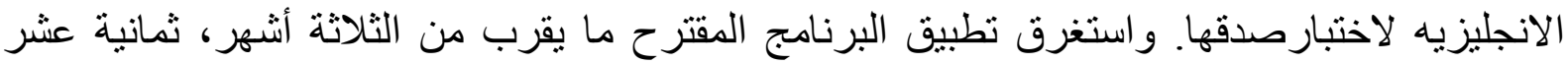

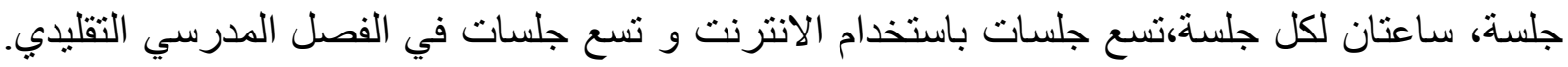

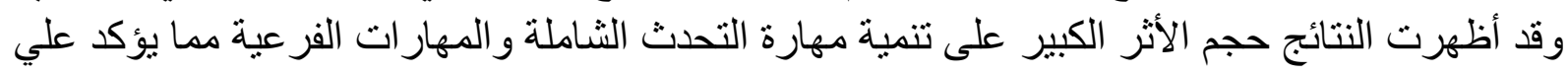
فاعلية البرنامج المقتر ح المستخدم لذلكئ.

الكلمات المفتاحية الرئيسية: التعلم التشاركي، التعلم المدمج،مهار ات التحدث، اللغه الاجنبيه الاولي- تعليم الكثروني. 